\title{
Pesticide use in banana and plantain production and risk perception among local actors in Talamanca, Costa Rica
}

\author{
Douglas Barraza $^{\mathrm{a}, \mathrm{b}, *}$, Kees Jansen ${ }^{\mathrm{b}}$, Berna van Wendel de Joode ${ }^{\mathrm{a}}$, Catharina Wesseling ${ }^{\mathrm{a}}$ \\ a Central American Institute for Studies on Toxic Substances, Universidad Nacional, Heredia, Costa Rica \\ ${ }^{\mathrm{b}}$ Technology and Agrarian Development Group, Wageningen University, The Netherlands
}

\section{A R T I C L E I N F O}

\section{Article history:}

Received 12 October 2010

Received in revised form

28 January 2011

Accepted 15 February 2011

Available online 10 March 2011

Keywords:

Pesticide risk perception

Banana and plantain

Costa Rica

Indigenous population

Agricultural worker

\begin{abstract}
A B S T R A C T
The Talamanca County in Costa Rica has large-scale banana and small-scale plantain production, probably causing pesticide exposure in indigenous children. We explored to what extent different community actors are aware of children's pesticide hazards and how their awareness related to socioeconomical and cultural conditions. Methods comprised eight focus groups with fathers and mothers separately, 27 semi-structured interviews to key actors, and field observations.

As a whole, the indigenous plantain farmers and banana plantation workers had some general knowledge of pesticides concerning crop protection, but little on acute health effects, and hardly any on exposure routes and pathways, and chronic effects. People expressed vague ideas about pesticide risks. Inter-community differences were related to pesticide technologies used in banana and plantain production, employment status on a multinational plantation versus smallholder status, and gender. Compared to formalized practices on transnational company plantations, where workers reported to feel protected, pesticide handling by plantain smallholders was not perceived as hazardous and therefore no safety precautions were applied.

Large-scale monoculture was perceived as one of the most important problems leading to pesticide risks in Talamanca on banana plantations, and also on neighboring small plantain farms extending into large areas. Plantain farmers have adopted use of highly toxic pesticides following banana production, but in conditions of extreme poverty. Aerial spraying in banana plantations was considered by most social actors a major determinant of exposure for the population living nearby these plantations, including vulnerable children. We observed violations of legally established aerial spraying distances.

Economic considerations were most mentioned as the underlying reason for the pesticide use: economic needs to obtain the production quantity and quality, and pressure to use pesticides by other economic agents such as middlemen. Risk perceptions were modulated by factors such as people's tasks and positions in the production process, gender, and people's possibilities to define their own social conditions (more fatalistic perceptions among banana workers). The challenge for the future is to combine these insights into improved health risk assessment and management that is culturally adequate for each particular community and agricultural context.
\end{abstract}

(c) 2011 Elsevier Inc. All rights reserved.

\section{Introduction}

In Costa Rica, environmental contamination and human pesticide exposure have been documented in relation to banana production with studies focusing on workers' exposure and health effects (van Wendel de Joode et al., 1996, 2001; Wesseling et al., $1996,2001)$ and on aquatic pollution and eco-toxicological effects (Castillo et al., 1997, 2000). Less attention has been paid to impact

\footnotetext{
* Corresponding author at: Central American Institute for Studies on Toxic Substances, PO Box 86, Heredia 3000, Costa Rica.
}

E-mail address: dbarraza@una.ac.cr (D. Barraza). of pesticide use on communities that border with, or lie within the boundaries of banana and plantain farms.

Costa Rica is the world's third largest exporter of bananas, following Ecuador and the Philippines. In 2007, banana plantations covered almost 49,000 ha, 2.1 million metric tons were exported with revenue of US\$ 659 million, and the plantations provided direct employment to some 35,000 workers (CORBANA, 2009). Although the contribution of the banana industry to the gross domestic product decreased from an average $4.2 \%$ in the period of 1980-1992 (Murillo-Sánchez, 1998) to 2.5\% in 2007 (CORBANA, 2009), banana continues to be an equally important export product in absolute figures, a source for foreign exchange, and one of the main agricultural activities of the country. Banana production is located in the Caribbean coastal region, where high 
rainfall and the soils are the most suitable. Although plantain is less important economically for the country, it is a common part of the diet in many Latin American countries. Plantain is grown widely in the Caribbean coastal region, mostly by small-scale farmers both for local consumption and for export. Banana production consumes half of the pesticide imports in Costa Rica (Ramírez et al., 2009), whereas plantain traditionally has been less dependent on chemical treatments. Studies in relation to plantain production are still scarce, but show that pesticide use has recently increased, also by indigenous people in Talamanca (Polidoro et al., 2008). Given the particular situation of the children who live, play, go to school and, in case of smallholders, sometimes work near or in banana and plantain fields, it was expected that they would be exposed to high levels of pesticides.

The objective of this study was to explore to what extent different community actors in Talamanca are aware of children's pesticide hazards in large-scale banana and small-scale plantain production areas, and how their awareness relates to socioeconomical and cultural conditions. The former, because child health is not an isolated issue but closely related to occupational and environmental conditions and general community aspects. This study was undertaken in tandem with an epidemiological project, that will be published separately, in which the effects of pesticide exposure on children's neurobehavioral development were assessed and used an ecosystem health approach (Forget and Lebel, 2001).

This study contributes to a small but growing body of research on pesticide risk perceptions that argues that pesticide reduction strategies cannot simply be derived from natural science-based risk analysis. Such research line extends technical studies on pesticide risks, which conceptualize risk as the 'probability of harm', by focusing on risk as a social construct in which an acceptable risk is not an outcome of objective scientific measurement but a socially accepted risk (Boudia and Jas, 2007; Guivant, 2003; Jansen, 2003; Turner, 2001). It intends to reveal how risk perceptions are filtered by social and cultural meanings and transmitted via social groups and relations. It investigates why people emphasize certain risks, technology options, or risk reduction strategies while ignoring others. Existing evaluations of exposures and health effects in Costa Rica have not yet taken into account the importance of such social and cultural factors, thus limiting the policy relevancy of laboratory and epidemiologic research results. This study complements the very few studies that have examined and quantified to some extent farmers' perceptions of pesticide risks in Costa Rica (Galt, 2007; Polidoro et al., 2008) and explored the link between agrarian modernization and pesticide use (Galt, 2008; Murray, 1994; Thrupp, 1988). It aims to identify how attitudes, beliefs, practices, perceptions and needs are embedded in the social, economic and cultural context of the populations. It compares lay knowledge with existing scientific knowledge.

\section{Methods}

\subsection{Setting}

The Talamanca County, located in the Caribbean coast of Costa Rica, has the lowest Human Development Index in Costa Rica (PNUD-UCR, 2007) and includes the Bribri Indigenous Territory. In 2004, the Universidad Nacional in Costa Rica started a program with indigenous communities in Talamanca to improve people's quality of life. Several stakeholders, in particular the local government of the Indigenous Territory (ADITIBRI) and the Indigenous Women Association ACOMUITA expressed concern to university representatives over pesticide contamination and supported to study pesticide issues in Talamanca.

Initially, the larger project was presented to community (ADITIBRI, ACOMUITA, Talamanca Organic Smallholders Organization (APPTA)), governmenta organizations (Ministries of Health, Agriculture, and Education, Municipality,
Social Health Security), and banana enterprises. From these meetings onwards, the snowball technique was used to identify key actors, including local officials of different governmental sectors, employees of transnational banana companies, local non-governmental organizations (NGOs), and community leaders. All pertinent key actors were identified, since we contacted each actor mentioned by any of the interviewees until no new actors emerged in the study area.

Based on discussions during the community presentations we selected two communities to study parent's pesticide risk perceptions with more detail: one with banana and the other with plantain cultivation. These communities, Daytonia and Shiroles, were consistently mentioned as having high exposure to pesticides, and populations composed by indigenous agricultural workers.

The population of Daytonia, situated outside the Bribri Indigenous Territory, is composed mainly of banana workers of the Chiriquí Land Company and their families, with a large majority of indigenous Ngöbe people, migrants from Panama, and a minority of migrants from Nicaragua and native Costa Ricans. All Ngöbe women stay at home while their husbands work on the plantations. The community is surrounded by banana plantations with modern production technology such as small aircrafts and helicopters to spray fungicides, the use of PPE, access to a solid market to sell the product, and labor division, which includes an almost continuously aerial and terrestrial pesticide applications.

The population of Shiroles lives inside the Bribri Indigenous Territory and consists mainly of Bribri (95\%) (Rioux-Pelletier, 2009) with smaller numbers of Cabécar and mestizos (mostly married into the community). Compared to other rural areas in Costa Rica there is a much higher level of female farming; the Bribri are a matrilineal society in which women have a substantial control over land and manage farms independently (Borge and Villalobos, 1994). Farmers practice small-scale plantain production, with an average farm size of 2.8 ha (Polidoro et al., 2008) as the main commercial agricultural activity, partly for export. The use of pesticides is higher than in other villages in the Indigenous Territory (Polidoro et al., 2008). According to the local indigenous people, pesticide use in the Indigenous Territory started some 20 years ago.

\subsubsection{Data collection}

Our research, conducted in Talamanca between 2006 and 2007, integrates three different qualitative techniques: focus group discussions, semi-structured interviews, and participatory as well as non-participant observation. The focus group discussions were held to better understand how perceptions, attitudes, and social representations were constructed (Basch, 1987) in the two villages. The semi-structured interviews were conducted to collect the opinions of key actors on different pesticide-related subjects (Veal, 2006). The combination of these methods made it possible to collect data on patterns in narratives, expressed views, and symbols. Through observations we assessed people's behavior in their everyday life, and correspondence and difference between expressed views and observed practice (Kellehear, 1993).

All participants in the focus group meetings and all interviewed key informants were informed that the larger project studied the impact of pesticides spraying in banana and plantain on children.

\subsection{Focus group discussions}

In each of the two communities a meeting was held for parents with children aged 6-9 at the public primary school. During this meeting the purpose of larger project was explained, and parents were asked for their collaboration. Parents who did not attend to the meeting where visited at home. Then, with the help of the teachers, invitations to talk about pesticide risks were sent to the parents who agreed to collaborate ( $n=49$ in Daytonia and $n=59$ in Shiroles). The groups ranged between 6 and 12 participants. Parents were around 30 years of age and had an average family size of five persons. Eight focus group discussions were held with the parents, mothers, and fathers in separate groups; four groups in each community. Participants were asked for permission to record the sessions, which were held in the local primary schools. The sessions of mothers were moderated by a woman psychologist with a male researcher as note-taker, and these roles were inversed for the fathers' sessions. The themes discussed with the parents of both communities covered the identification and function of pesticides, exposures, health consequences, information flows, and risk reduction strategies. Specific topics included children's activities at, and after school, parents' activities at the plantain farm or banana plantation and at home, work tasks of parents and children, use of personal protective equipment, pesticide storage, disposal of pesticide waste, cleaning of backpack sprayers, drinking water issues, and access to information on pesticides.

\subsubsection{Semi-structured interviews to key actors}

The first author (DB) applied semi-structured interviews to 27 local key actors representing different organizations and institutions (Table 1). Interviews lasted between $40 \mathrm{~min}$ and $2 \mathrm{~h}$. We did not achieve interview appointments with banana company managers in Daytonia and the health officials of the social security clinic attending the Indigenous Territory, despite several requests by telephone and visits. 
Table 1

Key actors interviewed in two hamlets of Talamanca.

\begin{tabular}{|c|c|c|c|}
\hline Affiliation and job title & & Daytonia & Shiroles \\
\hline $\begin{array}{l}\text { ADITIBRI (Developmental Association for Bribri's Indigenous People, Local Indigenous } \\
\text { Bribri Government) }\end{array}$ & President local government & & 1 \\
\hline Ministry of Education (primary schools) & Principals and teachers & 3 & 3 \\
\hline Ministry of Health (administrative offices in Bribri) & Physicians & $3^{a}$ & \\
\hline Ministry of Agriculture (Bribri) & Agricultural extensionist & $1^{\mathrm{a}}$ & \\
\hline Costa Rica Social Security (CCSS) Clinic of Sixaola & Primary health care technician and a nurse & $2^{\mathrm{b}}$ & \\
\hline \multirow{2}{*}{ Indigenous farmers } & Men & & 2 \\
\hline & Women & & 2 \\
\hline Local Health Committee of Daytonia (two men and a woman) & $\begin{array}{l}\text { Committee members (also key employees of banana } \\
\text { company) }\end{array}$ & 3 & \\
\hline Women Workers Banana Company & Packing plant workers & 2 & \\
\hline Workers' Union of Chiriquí Land (SITRACHIRI ) & Trade unionists & 2 & \\
\hline ACOMUITA (Women Association in Shiroles) & President NGO & & 1 \\
\hline Shiroles Educational Farm & Head & & 1 \\
\hline Total & & 16 & 11 \\
\hline
\end{tabular}

a These governmental agencies have their offices in the main village Bribri and attend both communities.

${ }^{\mathrm{b}}$ Referral health clinic for Daytonia.

\subsubsection{Observations}

Non-participant observations of people's activities were carried out during 3 months. In Daytonia, observations took place outside the banana plantations in and around people's houses and focused on people's activities after work and children's behavior with or without their parents' presence. We particularly looked at how people reacted when the aircraft for aerial spraying was approaching the village. In Shiroles, non-participant observations were done both on and off the farms. We kept a diary of daily activities of mothers, fathers, and children. Participant observation involved assisting in agricultural tasks such as removing the blue chlorpyrifos-treated plastic bags from the fruits, cutting down plantain plants, and carrying the bunches to the roadside for transportation.

\subsection{Data analysis}

The recordings of focus groups and interviews were transcribed verbatim within 3 days after the sessions, and later analyzed and coded using software for qualitative analysis (Atlas.ti v5). The transcript codes were arranged into major categories and below we will discuss five of them: 1) identification and function of pesticides; 2) pesticide exposure pathways; 3) health effects; 4) pesticide information flows; and 5) strategies to reduce pesticide exposures. The data obtained through observations were similarly coded, which facilitated triangulation.

\section{Results}

This section first reports on views expressed by respondents in the focus groups and interviews with regard to the five major categories. Subsequently it describes some observations which are relevant to interpret these expressed views. Tables 2 and 3 summarize the main results related to pesticide knowledge and risk perceptions obtained through focus group discussions and key actor interviews, respectively.

\subsection{Identification and function of pesticides}

Pesticides used on banana plantations were generally also used in plantain production. Respondents in the focus groups expressed a diversity of knowledge about pesticides with major differences between workers in Daytonia and farmers in Shiroles and between men and women. Instead of the term 'pesticide', participants from the banana community Daytonia mainly used the word 'poison' (veneno) while people from the plantain farming community Shiroles mainly used the word 'chemical' (químico). In Daytonia, fathers were familiar with the brand names of the most used pesticides (Table 2), but mothers could not mention any names. In Shiroles, on the contrary, specific names of pesticides sprayed on plantain were reported equally by fathers and mothers (Table 2). In Shiroles, women often apply pesticides, particularly the applications that were physically less demanding such as applying terbufos granules, which are poured directly from the bottle to the soil. They distinguished the brand names and the pests and diseases they were used for.

Mothers of both communities indicated that pesticides are hazardous for human health. The plantain farm mothers were especially concerned about the children's health. Fathers of both communities and plantain farm mothers considered that pesticides were needed to produce the fruits and that not using pesticides would imply an economic burden. In the banana community fathers put forward that, without pesticides, the black sigatoka disease (Mycosphaerella fijiensis) would destroy plantations resulting in unemployment and increased poverty. In the plantain community, the farmers framed the economic imperatives somewhat differently: pesticides were necessary because the middlemen buying the plantain harvest paid just a third of the market value if there were spots on the plantain skin.

Interviews: The various interviewed key actors generally expressed that pesticides are toxic but related their concerns to different issues. Officials of the Ministry of Health acknowledged human and environmental risks, but expressed that pesticides had boosted agriculture and are a necessary technology to eliminate pests. School teachers from both communities considered poor knowledge about health and environmental risks as the main problem. Social Security staff pointed to improper pesticide handling and insufficient medical training of health officials regarding acute and chronic intoxications. For the director of the children's nutrition center in the banana village, pesticides are an adequate technology and the driving force that keeps everybody working: 'without pesticides Daytonia would not exist'. For the president of the women's association in the Indigenous Territory pesticides affect health and the environment. The president emphasized that síkuas (the term used for non-indigenous outsiders) brought pesticides into the Territory some 20 years ago and the Bribis and Cabécar adopted them when they observed that plantains grew faster using pesticides and fertilizers.

\subsection{Exposure pathways}

In the focus group discussions in the banana community of Daytonia, at first only few fathers and mothers acknowledged pesticide exposures or poisonings. Yet, as the discussions progressed, drift from aerial spraying was identified as a major exposure source for children and the entire community. In the plantain community Shiroles both fathers and mothers referred to 
Table 2

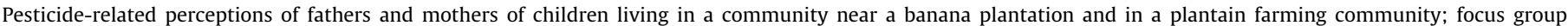
discussions, Talamanca, Costa Rica, 2007.

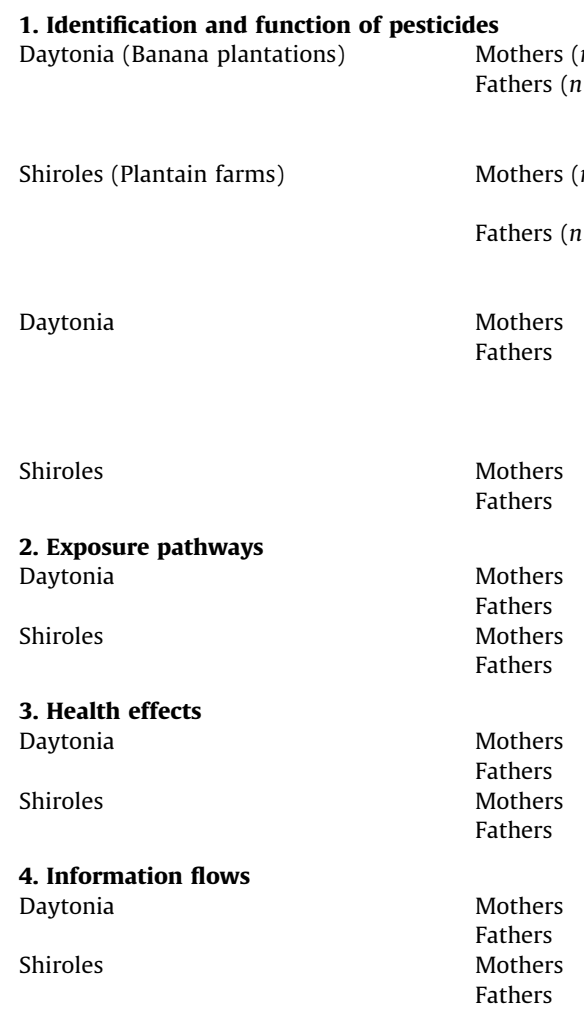

\author{
Poisons (venenos), especially dangerous for children \\ Poisons difficult to handle \\ Economic benefit for plantations \\ Little concern about risks for humans or environment \\ Chemicals (químicos) dangerous for humans and environment \\ Economic risk if not used \\ Good for the farm, bad for the soil \\ Economic risk if not used \\ No concern for human health or environment \\ Do not know which pesticides are used \\ Aerial spraying with fungicides mancozeb, chlorothalonil, tridemorf; plastic bags with \\ insecticides chlorpyrifos/bifenthrin; nematocides terbufos, fenamiphos, carbofuran, \\ ethoprophos; herbicides glyphosate and paraquat; pre-packing fungicides imazalil, \\ tiabendazole \\ Fungicides propiconazole, thiabendazole, imazalil; nematocides terbufos, oxamyl; \\ herbicides paraquat, glyphosate, 2,4-D, and plastic bags with insecticide chlorpyrifos
}

Daily, 365 days of the year, inside and outside the plantations from aerial and terrestrial applications

Children in the plantations; take-home pathways; domestic use of agricultural pesticides Children in the plantations; take-home pathways

Most common effects vomiting, diarrhea, headaches and skin rashes Did not mention

During and after applications frequently nauseas, diarrhea, headaches, dizziness and skin rashes

Scarce information from their husbands

Information from company training activities

Information from extension program of the Ministry of Agriculture, and from other farmers Previous jobs at banana companies with safe use training, partial reading of labels, and information from other farmers

5. Strategies to reduce exposure

Daytonia

Mothers

Fathers

Mothers

Fathers
Timely notifications for aerial pesticide spraying to keep children inside

Very difficult because it is a family business

Not to bring children in the farms while applying pesticides parental take-home exposure pathways, including direct contact between parents and small children at returning home after spraying. In both communities, mothers reported frequent domestic use of agricultural pesticides against rats, cockroaches, and mosquitoes. Both fathers and mothers reported the use of paraquat in the yard to control weeds.

In the interviews, the school teachers in Daytonia mentioned that the banana companies have offered the school occasional talks and reading materials about 'what to do during aerial spraying', but that nonetheless the information seems to be ineffective, since local people do not adapt their behavior during aerial applications. The personnel at the Ministry of Health put forward that children, women, and men in Daytonia are exposed to pesticides through multiple routes, digestive, respiratory and, in particular, dermal exposure, the latter because they have identified cases of people with skin allergies associated with pesticides. The women workers of the banana packing plant considered themselves exposed to pesticides since their job consists of splashing a pesticide on the banana hands with a hose before the fruits are placed in boxes. They did not know that this is a fungicide and had no idea of the active ingredient. They also mentioned drift from aerial sprayings into the packing plant, although they were assured that aerial spraying is under control since the aircrafts use sophisticated GIS equipment. Trade unionists identified, as the main source of contamination, the polluted waters in the banana plantation canals, which drain into the rivers contaminating fish and shrimps frequently consumed by the population. They also pointed out that people drink rain water collected from the roofs in the belief that this is clean water, but that it must be heavily contaminated with pesticides due to the frequent aerial sprayings nearby the houses.

\subsection{Health effects}

In the focus groups, mothers from the banana hamlet associated vomiting and diarrhea, common ailments in Daytonia, with aerial spraying of pesticides. They wondered whether pesticides are the cause of an outbreak of tuberculosis in the village. Fathers did not make such associations. Mothers from the plantain community mentioned skin rashes and poisoning symptoms (headaches, dizziness, nausea, diarrhea, and vomiting) to be very common in both children and adults during and after pesticide applications, but were uncertain about which pesticides caused most health effects. Some fathers from the plantain community stressed that, as long as there is no mouth contact, there should not be any health problem, whereas other fathers had noticed the same health problems after work on the farm as the mothers did. All of them agreed that diarrhea is very common in children after backpack spraying, especially in children between 6 and 12 years of age, who are usually present in the farm. Participants of both villages believed that men, women, and children are at equal risk of developing exposure-related health problems. Men in both villages and women in plantain plantations had heard about the sterility in men caused 
Table 3

Key actors' perception of pesticide risks in the Talamanca region.

\begin{tabular}{|c|c|c|c|c|c|}
\hline \multirow[t]{2}{*}{ Key actors } & \multirow[t]{2}{*}{ Community } & \multicolumn{4}{|l|}{ Pesticide risks } \\
\hline & & Causes or problems & Consequences & Main responsible & Solutions \\
\hline $\begin{array}{l}\text { Indigenous Local } \\
\text { Government ADITIBRI }\end{array}$ & Shiroles & $\begin{array}{l}\text { Contract farming, } \\
\text { unskilled farmers }\end{array}$ & $\begin{array}{l}\text { Increase of pesticide } \\
\text { use, land degradation }\end{array}$ & $\begin{array}{l}\text { Middlemen, national } \\
\text { market }\end{array}$ & $\begin{array}{l}\text { Improve marketing } \\
\text { chain }\end{array}$ \\
\hline Ministry of Education & Both & $\begin{array}{l}\text { Monoculture, no other } \\
\text { options for work }\end{array}$ & $\begin{array}{l}\text { Soil degradation; high } \\
\text { use of pesticides; } \\
\text { people and } \\
\text { environment exposed }\end{array}$ & $\begin{array}{l}\text { Government, public } \\
\text { policies }\end{array}$ & $\begin{array}{l}\text { Safe pesticide use } \\
\text { training, teachers can } \\
\text { contribute }\end{array}$ \\
\hline Ministry of Health & Both & $\begin{array}{l}\text { Large-scale banana } \\
\text { production }\end{array}$ & $\begin{array}{l}\text { Hazard to human and } \\
\text { environment }\end{array}$ & $\begin{array}{l}\text { Government, economic } \\
\text { policies }\end{array}$ & $\begin{array}{l}\text { Collaboration between } \\
\text { government, private } \\
\text { sector and local } \\
\text { communities }\end{array}$ \\
\hline Ministry of Agriculture & Both & $\begin{array}{l}\text { Monoculture, increase of } \\
\text { migrant workers } \\
\text { changed the social } \\
\text { structures, Costa Rican } \\
\text { indigenous people } \\
\text { adopted pesticide } \\
\text { technology }\end{array}$ & $\begin{array}{l}\text { Soil fertility depletion, } \\
\text { people more } \\
\text { subservient }\end{array}$ & $\begin{array}{l}\text { Transnational } \\
\text { companies, central } \\
\text { government agricultural } \\
\text { policies, migrants }\end{array}$ & $\begin{array}{l}\text { Train people on how to } \\
\text { use pesticide safely }\end{array}$ \\
\hline Social Security & Daytonia & $\begin{array}{l}\text { Monoculture, heavy } \\
\text { rains, insufficient } \\
\text { medical training in } \\
\text { pesticides }\end{array}$ & $\begin{array}{l}\text { Increasing aerial } \\
\text { pesticide spraying; air, } \\
\text { soil and water } \\
\text { pollution; people } \\
\text { exposed; not enough } \\
\text { knowledge how to } \\
\text { treat patients }\end{array}$ & $\begin{array}{l}\text { Government, } \\
\text { development policies; } \\
\text { medical faculties }\end{array}$ & $\begin{array}{l}\text { Better spraying } \\
\text { technology, } \\
\text { manufacturing industry } \\
\text { should educate people, } \\
\text { implementation of new } \\
\text { academic curriculums } \\
\text { on pesticides }\end{array}$ \\
\hline Shiroles farmers & Shiroles & $\begin{array}{l}\text { Bribris adopted outside } \\
\text { technology }\end{array}$ & Soil pollution & Outside buyers & $\begin{array}{l}\text { Training Bribris how to } \\
\text { handle pesticides }\end{array}$ \\
\hline Children's Nutrition Center & Daytonia & Banana enclave hamlet & Workers' exposures & Companies and workers & Not needed \\
\hline $\begin{array}{l}\text { Banana workers, trade } \\
\text { unionists }\end{array}$ & Daytonia & $\begin{array}{l}\text { Large-scale banana } \\
\text { production }\end{array}$ & $\begin{array}{l}\text { Pollution of canals, } \\
\text { rivers, soil, and air; } \\
\text { subsequently people } \\
\text { exposed }\end{array}$ & The banana companies & $\begin{array}{l}\text { Move the village to } \\
\text { another place }\end{array}$ \\
\hline $\begin{array}{l}\text { Indigenous Women's } \\
\text { Association }\end{array}$ & Shiroles & $\begin{array}{l}\text { Costa Rican indigenous } \\
\text { people adopted } \\
\text { hazardous technology } \\
\text { from sicuas (outsiders) }\end{array}$ & $\begin{array}{l}\text { Depletion of soil } \\
\text { fertility with increase } \\
\text { of pesticides use }\end{array}$ & $\begin{array}{l}\text { Sicuas and local } \\
\text { indigenous people }\end{array}$ & $\begin{array}{l}\text { Uses of indigenous } \\
\text { knowledge to improve } \\
\text { soil fertility }\end{array}$ \\
\hline Shiroles Educational Farm & Shiroles & Contract farming & $\begin{array}{l}\text { Increase of pesticide } \\
\text { use; people exposed to } \\
\text { pesticides; decrease of } \\
\text { plantain yield }\end{array}$ & $\begin{array}{l}\text { Middlemen and local } \\
\text { indigenous people }\end{array}$ & $\begin{array}{l}\text { Improve marketing } \\
\text { chain }\end{array}$ \\
\hline
\end{tabular}

by dibromochloropropane (DBCP) in other counties of the region (Slutsky et al., 1999; Bohme, 2008) and felt uncertain and anxious about the effects of pesticides on reproductive health.

In the interviews in Daytonia, trade unionists noted that many people in Talamanca had either personally experienced a pesticide poisoning or knew someone else who had. They identified symptoms frequently experienced by workers, which they thought were related to pesticides exposure, specifically diarrhea, vomiting, headaches, itching, rashes, allergies, and respiratory asthma-like symptoms. Workers mention such health problems but do not necessarily relate them with pesticides exposure. On the contrary, the members of the local health committee of Daytonia, which is composed by key employees of the banana companies, stated that pesticides might pose a health hazard but that pesticide management is so well organized that nothing bad could happen to the population. According to them, a more important health issue would be that temporary workers are disease carriers of, for example, tuberculosis. One actor in the health sector also referred to tuberculosis while talking about pesticide issues: the director of the nutrition center did not perceive pesticides as a health problem for the community, but rather that Ngöbe people bring infectious diseases like tuberculosis and diarrhea into the area. Other actors in the health sector emphasized other issues. Personnel at the social security pointed at protocols followed for poisonings by organophosphates, such as the extremely toxic terbufos, which they saw as potentially fatal. They were uncertain about other pesticide-related illnesses. The representatives of the Ministry of Health recognized respiratory problems, skin allergies, asthma, and digestive disorders as most common pesticide-related health problems. In Shiroles, interviewees voiced little concern about health risks in the community as a consequence of pesticide use. Only the problem of the chlorpyrifos bags ending up in the village and in the streams when it rains was expressed by some of the interviewed actors and reflected in the temporary establishment of the so-called 'Recycle Committee of Shiroles'. However, measures to reduce the littering of bags and other plastic containers have failed so far.

\subsection{Information flows}

In the focus groups, mothers from the banana community of Daytonia reported that the little they know about pesticides they had heard from their husbands. The fathers, on the contrary, had received training in pesticides from the company, by means of team meetings, workshops, and leaflets (mostly about black sigatoka control and aspects of occupational hygiene for the worker; not about risks for the community). Exchange of information about pesticides between workers or between women was not mentioned. In the plantain community of Shiroles, mothers had received some technical information about pesticides from the agricultural extension program of the Ministry of Agriculture. Several of the plantain fathers with a work history in 
the banana companies recognized this as a source of information. Although they were trained in the safe use of pesticides they said they did not apply this knowledge on their own farms. Other fathers said that they obtained information from reading the labels. They also mentioned that they only read how to prepare the mixture and not about possible adverse health effects. In addition, fathers indicated that they get information from fellow farmers on what to use. While the focus group meetings developed, participants emphasized the need for more information for parents about the potential negative effects of pesticides in human health, especially children.

In the interviews it was evident that governmental agencies do not inform local communities about pesticide risks. Representatives from CCSS and school teachers considered themselves poorly informed on pesticides issues and expressed the need for more evidence-based information, e.g. on how to wear personal protective equipment. In Shiroles, the need for environmental education in the community for pesticide waste management was raised. Several actors pointed out the need for information on non-chemical alternatives to pesticide use.

\subsection{Strategies to reduce pesticide use and exposure}

In the focus groups parents of the banana plantation community mentioned the need for notifications about when and how long the aerial spraying will take place, so mothers could keep the children inside the house to avoid direct contact with pesticides. In Shiroles, most of the interviewed people mentioned that in order to reduce pesticides exposure, a good training program is needed on how to handle pesticides safely.

In the interviews, representatives of the Costa Rican Social Security maintained that the manufacturing industry should educate the people in the village about technical and health aspects of pesticides. Also in Shiroles, safe use training for the entire community was mentioned as a possible strategy both by the Women Association and the Local Indigenous Government. The school teachers from both villages saw a role for themselves, but needed more training and educational materials. The strategies to reduce pesticide use in Daytonia were considered by the majority of the interviewed actors as a very difficult task. In fact, everybody recognized a problem but few solutions were proposed. Those few concrete solutions that were mentioned to reduce exposures of children or themselves seem rather unfeasible in the short term, such as the construction of a pipeline to conduct uncontaminated drinking water from the forest to the population (school teachers) and, even more drastic, to move the entire village to a place far from the banana plantations (trade union representatives). Risk reduction strategies mentioned by different key actors ranged from very drastic in Daytonia (removal of the hamlet to another place) to conventional in Shiroles, where the most mentioned one was to train farmers, their families, NGOs and local authorities on safe management of pesticides as well as possible negative effects to human and environmental health. Governmental actors serving both communities emphasized concerns related to human and environmental contamination from pesticide use on banana plantations, as did actors of the banana community. Actors of the Indigenous Territory expressed particular concern related to increase in pesticide use leading to soil degradation (Table 3 ).

\subsection{Observations}

\subsubsection{Banana community Daytonia}

The plantations are right next to where people recreate and live, without major vegetation as natural barriers. The distances between the plantations and the houses were on average $17 \mathrm{~m}$, while the school, the soccer field and play areas were located at $12 \mathrm{~m}$ or less from the plantations. After several days of heavy rain (when aerial spraying is suspended), the spraying pattern increased from two to four cycles of aircraft flights per day and sometimes two aircrafts spraying simultaneously were observed. We observed how people, houses, play grounds, clothes hung out to dry, and toys in the gardens got wet from the pesticide mist in the air following aerial applications. Cars, roofs, and school tables were turned yellow.

Some mothers would take the youngest children inside the houses during aerial spraying but others did not. In the houses, life went on as if nothing was happening. People did not collect toys or clothes that were outside. Around the houses there are fruit trees, like yuplón (Spondias dulcis), carambola (Averroha carambola), and mango (Magnifera indica). Children generally eat the fruits without washing them. Although there is a regulation from the school's Principal that all teachers have to call children to shelter when there is aerial spraying, only some teachers did so and a considerable number of children just continued their activities outside. When we asked them if they thought that this would put them in danger, they said "We do not feel anything bad". Although the presence of children inside the banana plantations is strictly forbidden, we observed children play there "hide and seek". When we asked them if they were aware that this is forbidden, they replied "Where else can we play?" The only places where children can play in Daytonia are the soccer field and the grounds around the school, both surrounded by the plantations. We observed that most girls and boys play barefoot in the soccer field or inside the plantations.

\subsubsection{Plantain community Shiroles}

In the Indigenous Territory, the farms were located at a considerable distance, at least $2 \mathrm{~km}$, from the village and most houses. Men, women, and children all participated in different stages of agricultural plantain production, including cleaning the soil, sowing, pruning, and harvesting the final product. Single mothers performed all tasks with their children. Families went to the farms before $7 \mathrm{am}$ and returned home around noon, or in the weekends returned later in the afternoon. Both fathers and mothers applied pesticides, and boys as well as girls from age 10 placed chlorpyrifos-treated bags around the fruit (these bags protect the plantain against insects). Smaller children were often present in the farm, also when the parents were spraying pesticides, though we did not observe the presence of babies or toddlers since these were left in the care of relatives. Adults wore rubber boots, children working or playing on the farms were barefoot. Women always used long sleeved shirts and long trousers, contrary to the men, to protect themselves from the sun. Both fathers and mothers wore a neckerchief to clean the forehead of sweat.

The families usually took some snacks or lunch and water to the field, which they hung with other belongings in the 'rancho', a structure of four poles with a zinc roof and a bench in the middle of the farm. They had no reservations about eating while someone else was applying pesticides. We did not observe people washing their hands before eating. During the night, often one of the men of the family would sleep in the rancho to prevent theft of the plantains. We observed that the pesticide dregs were spilled on the soil of the farm and leftovers were stored in refreshment bottles and hidden on the farm to prevent thefts. The backpacks were rinsed in the nearby streams and the chlorpyrifos-treated plastic bags were littered anywhere in the farms and the village. When the family returned to their houses, parents hugged the babies and toddlers still wearing their contaminated working clothes. These clothes were washed every day together with the rest of the clothes of the family by hand or in a washing machine. 


\section{Discussion}

\subsection{Continuities and discontinuities between people's knowledge and expert knowledge}

This section compares people's knowledge on pesticides and pesticide risks as expressed in the interviews and focus groups as well as the data from additional observations with expert knowledge as expressed in the scientific literature and within the community of occupational health specialists. From the latter perspective it could be argued that the indigenous plantain farm-workers and banana plantation workers as a whole have some general knowledge of pesticides when it concerns identification and crop protection effects, but have little knowledge on acute health effects (basically based on their own observations and personal experiences of serious accidents) and hardly any knowledge on exposure routes and pathways and chronic effects. Because of the high level of pesticide use with potential higher exposures and the formalized rules of pesticide handling on plantations, we expected people in the banana village to be more knowledgeable of pesticide risks than people in the plantain village. However, the analysis of the data does not confirm this hypothesis.

Pesticides reported in banana and in plantain production included moderately (class II, e.g. paraquat, chlorpyrifos), highly (class Ib, e.g. fenamiphos, oxamyl), and extremely (class Ia, e.g. ethoprophos, terbufos) toxic pesticides according to the WHO recommended classification of pesticides by hazard (WHO, 2010). Besides acute risks many of the reported pesticides also pose risks of chronic toxicity including endocrine disrupting effects (e.g. chlorpyrifos, mancozeb), neurodevelopmental effects (e.g. chlorpyrifos, terbufos), allergies (e.g. chlorothalonil, mancozeb), cancer (e.g. mancozeb, chlorpyrifos), and contact dermatitis (e.g. glyphosate, paraquat) (IRET, 2010). The use of pesticides with high acute and chronic toxicity and the related health and environmental impact is in general terms similar to the situation in other largeand small-scale agriculture settings in Central America and the developing world in general (Eddleston et al., 2002; Jansen, 2002; Galt, 2008; Murray and Taylor, 2000; Sherwood, 2009; Wesseling et al., 2001).

The data show that many people express vague ideas about pesticide risks but have little precise knowledge of occupational exposures and health risks. In general terms the workers in Daytonia reported protective and control measures for different jobs and felt protected, as one worker stated: "Probably we are not really in danger because we are obliged by the company to wear protective equipment and if you are caught by the supervisor without protection, you are fined". In this study we could not verify the level and adequacy of use of personal protection equipment (PPE). However pesticide exposure reduction due to PPE use seems limited as both past and recent studies on banana plantations workers in Central America who used PPE showed important pesticide exposures (van Wendel de Joode et al., 1996; Rodríguez et al., 2006; Wesseling et al., 2006) and health risks including acute poisoning (Vergara and Fuortes, 1998; Wesseling et al., 1993, 2001, 2006), irritant and allergic contact dermatitis (Penagos, 2002; Wesseling et al., 2001), respiratory effects (Castro-Gutiérrez et al., 1997), cancer (Wesseling et al., 1996; Hoffmann et al., 2006), neurobehavioral effects (Wesseling et al., 2002, 2006), including suicidal ideation (Wesseling et al., 2010), and male sterility (Slutsky et al., 1999). Our interview and focus group data confirm the findings of other studies in the sense that people believe that they are protected when safety rules at their workplaces are strictly implemented (Rao et al., 2007).

Compared to current formalized pesticide handling practices on transnational company plantations, pesticide handling by plantain smallholders seems less adequate, with selection of inappropriate pesticide for pest control, lack of training, unavailability of personal protective equipment, faulty spraying equipment, lack of storage facilities, nonobservance of personal hygiene measures during and after spraying, and direct involvement of children in pesticide use. The conditions on the farms of Shiroles are similar to conditions of other farmers in Central America, specifically of subsistence farmers in Nicaragua (Aragón et al., 2001) and Honduras (Jansen, 2002). Similar, also, is the general lack of risk awareness as reported among the Nicaraguan farmers with regard to their own health. The first reaction of both men and women farmers in Shiroles was that they did not need more protection, even when recognizing the presence of poisoning symptoms or skin injuries during discussions or deeper questioning. The use of long sleeved shirts and pants by women sprayers was for esthetic reasons, as they wished to stay free of spots on their skin whereas men sprayed in shorts and t-shirts. Safety precautions were hardly an issue for farmers. The health symptoms that respondents mentioned are in agreement with known symptoms of poisonings or pesticide adverse effects reported in the literature.

Even though occupational safety was not perceived as deficient by the workers on banana plantations, the aerial spraying in banana plantations was considered a major determinant of exposure of the entire population with minimum distances and no natural barriers, one of them noted: "Here where we live, when the airplane sprays, the air gets wet and I suppose everybody is in contact. The aerial spraying is meant for the plantations, but the air moves....". By law, spray nozzles of the aircraft must be closed appropriately and timely when approaching populations and waterways. According to the current regulation (República de Costa Rica, 2003), when applying pesticides by aerial spraying, a minimum distance of $30 \mathrm{~m}$ between the houses and the banana plants is required as a buffer zone in the case that a natural barrier (a layer of at least $30 \mathrm{~m}$ of trees higher than the banana plants) exists, whereas without natural barriers this distance must be at least $100 \mathrm{~m}$. None of these regulations were being followed in the area. All testimonies as well as our own observations corroborated that in Daytonia there is a continuous violation of the current legal regulations in banana cultivation. In addition, nothing is being done to reduce the exposure, not even for children as a vulnerable population. The children do not follow any hygiene rules such as taking showers or washing their hands and faces after being exposed to the aerial spraying, since they nor their parents are aware of the hazard they are dealing with. Similarly, key actors indicated to have little access to adequate information and low levels of understanding or awareness of involved risks.

\subsection{Perceptions of the underlying causes of pesticide risks}

Though key actors and participants in focus group discussion could not indicate the many aspects of an expert type of risk assessment, they had some general notion of pesticides as 'dangerous things' that should be handled carefully and which may cause harm. Many informants did present views on some of the major drivers underlying pesticide risks. They basically pointed at two issues that also appear often in the literature on pesticides: monocultures and economic needs.

Large-scale monoculture was perceived as one of the most important problems leading to pesticide risks in Talamanca. Key actors repeatedly mentioned that monoculture increases pest occurrence and consequently banana companies need to use more and more pesticides to assure their production. The pesticide use pattern on banana plantations corresponds to high input requirements of extensive monocultures with some $40 \mathrm{~kg} / \mathrm{ha} / \mathrm{yr}$ of active ingredient (Castillo et al., 1997, 2000). This use pattern applies to plantain producing farmers in Shiroles too, as the 
growth of plantain production of many bordering small farms has led to a large area where pest and diseases spread as in a large monoculture estate. Many of these farmers are adopting part of the pest control technologies used in the banana industry. They use the same pesticides as the companies, but in conditions of poverty implying not only the lack of economic resources to implement safety precautions such as PPE, but also general social and health conditions that aggravate either exposure or susceptibility for adverse effects. Extensionists of the Ministry of Agriculture have played an important role in promoting pesticide technology among indigenous farmers.

Economic considerations are mostly mentioned as the underlying reason for the high or increasing pesticide use. In Daytonia, without banana production, there would be 'no jobs, no people, and no village', as the Director of the nutrition center phrased it. Under these conditions, little attention is paid to pesticide hazards. Many of the workers come from impoverished villages in Panama without employment opportunities. The dilemma of the Daytonia people is either to continue with their only possibility to earn their living or to return to their home villages where there is extreme poverty. Two different elements can be distinguished: economic needs and pressure by other economic agents. The data section provides several examples where informants refer to economic needs: if banana is not being sprayed in Daytonia the people 'will lose their jobs'; smallholders in Shiroles spray 'in order to make a living' with plantain cultivation.

This general argument of economic needs is complemented in Shiroles with another argument related to the sphere of markets. It is an argument that fits into the local discourse of farmers being exploited by middlemen and shifts the blame of the pesticide problem, in a context where pesticide contamination is a societal concern discussed among the population, from the local people to external agents. In Shiroles small farmers have little negotiation power and are subjugated to the requirements set by the middlemen: plantain bunches must have at least 35 fingers, without spots, which results in an upward pressure on pesticide use. In addition, the middlemen push producers to use chlorpyrifostreated bags so that they can sell them these bags. Farmers who cannot show the middlemen the used blue chlorpyrifos-treated bags receive a lower price. This push by middlemen is not simply about the quality of plantain, but also a consequence of their sales interests. Even the largest farmers in Shiroles are bound to hierarchical interactions with middlemen, since they have no direct access to the next level of the chain (markets, supermarkets, etc.). Such hierarchical interactions likely influence farmers' risk perception. Having no option to avoid the use of the toxic bag, they question mainly the extra costs but hardly the health aspects.

\subsection{Explaining differences in perceptions of pesticide risks}

Although the research design originally did not focus on the origins of the differences in pesticide risk perceptions, the available data on these differences allow us to draw some preliminary conclusions. Firstly, different gender roles shape the knowledge about pesticides. This knowledge is not inherent to being a man or a woman but results from one's position in the labor process (Jansen, 2000). This is best illustrated with a comparison of Daytonia and Shiroles; we encountered a clear gender difference in knowledge and risk perception in the plantation community but not in the indigenous farming community. In the former, only men knew which pesticides were being used and for which purpose, whereas the women were completely unaware. In the latter, where women have their own farms, make decisions about pesticide use, and apply pesticides, women had as much knowledge as men did.
Secondly, one's position in the labor process shapes the perception of pesticide risks which is reflected in who people blame when something goes wrong (Guivant, 2003; Jansen, 2008). For example, local farmers in Shiroles blame the middlemen, officials of various ministries point at the implementation of policies, and trade unionists point at the large companies (Table 3 ). Interesting is also the dichotomy in the use of different words for pesticides (Palis et al., 2006). Plantation workers in Daytonia use a more negative word (poison) whereas farmers in Shiroles, who themselves decide that they use pesticides, use the more neutral word 'chemical'. These farmers have often been plantation workers before, but now, in a different position, use a different terminology.

Thirdly, not only people's tasks and position in the production process push health considerations to the back, but also people's possibilities to define their own social conditions. In Daytonia workers perceive that others largely determine what is risky, since they have no role to play in the decision-making process. These individuals often prefer to be unaware of the unavoidable danger and often express in fatalistic terms the effects of pesticides ('it is in God's will' whether or not pesticides will affect our health) or their possibilities to do something about it. From Cultural Theory it can be derived that this fatalism should be regarded not so much as a psychological state of the individual but as a result of the specific form of social organization (Vellema, 2005). This means that this fatalism could be transitional if workers would feel more empowered to make collective requests to the company, for instance, related to warnings to the dwellers about the exact time the aircraft will be spraying pesticides and more information about health effects from pesticide exposures, in particular children's health. Farmers in Shiroles are probably more empowered than plantation workers in Daytonia to achieve strategies proposed by the community members, since they are the owners of their smallholdings. In Shiroles, the interviewees expressed themselves in less fatalistic terms about the possibility for strategies to reduce exposure to pesticides and minimize possible negative effects on human health.

This connects with the fourth source for differences in pesticide perceptions in this case: several contingently related political struggles that dissipate into the arena of pesticide perceptions. The Women Association ACOMUITA linked in interviews the issue of the contamination of pesticide-treated blue bags with 'outsiders' (basically mestizo men marrying with indigenous women) who increasingly exercise control over land in the territory and threaten existing local institutions that regulate land rights. In her view, her fellow farmers have a short term vision, seeing only the money they get at harvest time and not seeing the damage they are causing to Mother Earth by using pesticides (Nygren, 1998). She worries that the soil will be exhausted in the near future if nobody takes steps to stop this contamination. In this case, other social concerns triggered, or at least intensified, local concerns about pesticide contamination. Such a mechanism was not present in Daytonia.

Finally, difference in pesticide perceptions is an outcome of the research process itself and again shows that pesticide perceptions are not static opinions but shaped by social activity. In the course of several of the focus group discussions a clear agreement between participants emerged that aerial spraying was unsafe and considered a particular risk for children. Fathers and mothers increasingly talked about potential additional exposures when children play inside the plantations. Simply raising some questions about the issue stimulated the participants to talk about it and to generate as a group a new awareness about the issue. During the time the study was conducted, the overall perception that pesticides are an occupational and environmental health risk, especially for children, emerged more strongly as a consequence of the participatory nature of the study. The study triggered concerns and, in Shiroles, promoted some initial actions to reduce risks. 


\section{Recommendations}

The reduction of pesticide exposure risks in Talamanca is a complex process since multiple economic interests prevail. We recommend a participatory and multi-actor approach for a risk reduction program at community, regional and national level, involving individuals, NGOs, state regulatory agencies, the multinational banana companies, and any other pertinent actor, which should go far beyond education, hygienic measures, and use of personal protective equipment. Such program should implement risk reduction measures at the source such as cutting back on pesticide use by promoting agro-ecological practices and the use of integrated pest management. For the smallholders, this should go hand in hand with measures to guarantee better market access, for example by facilitating the organization of the smallholders to minimize the influence of middlemen. Other possible measures are to procure larger distances between communities and plantations, and to obtain a better compliance of aerial application regulations through improved surveillance in which communities must have an active role. The implementation of such measures takes time. Therefore, as a first step we recommend to increase awareness of pesticide risks among all actors through workshops where national data on pesticide exposure and health effects are discussed; and as a second step, to organize discussion forums on contextualized pesticide exposure reduction strategies with an analysis of the realistic possibilities of the different actors and responsibilities within a legal framework.

\section{Conclusions}

This study describes how people's knowledge (workers, farmers, state officials, and others) about the risks of being exposed to pesticides differs from expert notions of safety and appropriate pesticide handling and use. Several remarkable differences between both hamlets as well as within hamlets were found, including differences in technologies of pesticide applications in banana and plantain production, employment status on a multinational plantation versus smallholder status, gender differences, extent of control over the own social environment, and presence of social conflicts to which pesticide dangers are being discursively related (in the case of Shiroles). The challenge for the future is to combine these insights with conventional approaches to pesticide risk assessment in order to generate enhanced study designs of health risk assessment and to design and implement exposure reduction strategies that are adequate for each community and feasible in each particular agricultural context.

\section{Acknowledgements}

The authors thank Leonel Córdoba and Marianela Rojas of IRET-UNA, and Linda Sosa of CINBIOSE, University of Quebec at Montreal, Canada for all their assistance during the field work. Wageningen School for Social Sciences (WASS, CERES-CEPIP fund) and the International Development Research Centre (IDRC) funded this research. The Ethical Scientific Review Committee of the Universidad Nacional approved the study.

\section{References}

Aragón, A., Aragón, C., Thörn, A., 2001. Pests, peasants, and pesticides on the northern Nicaraguan pacific plain. International Journal of Occupational and Environmental Health 7, 295-302.

Basch, C.E., 1987. Focus group interview: an underutilized research technique for improving theory and practice in health education. Health Education and Behavior 14 (4), 411-448.
Bohme, S.R., 2008. DBCP in the United States and Central America: body, nation, and transnationalism in the history of a toxic product. Ph.D. Dissertation, Brown University.

Borge, C., Villalobos, V., 1994. Talamanca en la encrucijada. EUNED, San José.

Boudia, S., Jas, N., 2007. Introduction: risk and 'risk society' in historical perspective. History and Technology 23 (4), 317-331.

Castillo, L., de la Cruz, E., Ruepert, C., 1997. Ecotoxicology and pesticides in tropica aquatic ecosytems of Central America. Environmental Toxicology and Chemistry $16(1), 41-51$.

Castillo, L., Ruepert, C., Solis, E., 2000. Pesticide residues in the aquatic environment of banana plantation areas in the north atlantic zone of Costa Rica. Environmental Toxicology and Chemistry 19 (8), 1942-1950.

Castro-Gutiérrez, N., McConnell, R., Andersson, K., Pacheco-Antón, F., 1997. Respiratory symptoms, spirometry and chronic occupational paraquat exposure. Scandinavian Journal of Work, Environment and Health 23, 421-427.

CORBANA, 2009. Origen de la industria bananera en Costa Rica. 〈www.corbana. co.cr > (accessed January 28, 2009). 〈www.corbana.co.cr >

Eddleston, M., Karalliedde, L., Buckley, N., Fernando, R., Hutchinson, G., Isbister, G. Konradsen, F., Murray, D., Piola, J.C., Senanayake, N., Sheriff, R., Singh, S. Siwach, S.B., Smit, L., 2002. Pesticide poisoning in the developing world-a minimum pesticides list. The Lancet 360 (12 October), 1163-1167.

Forget, G., Lebel, J., 2001. An ecosystem approach to human health. International Journal of Occupational and Environmental Health 7 (2), 3-38.

Galt, R., 2007. Regulatory risk and farmers' caution with pesticides in Costa Rica. Transactions of the Institute of British Geographers 32 (3), 377-394.

Galt, R.E., 2008. Pesticides in export and domestic agriculture: reconsidering market orientation and pesticide use in Costa Rica. Geoforum 39 (3), 1378-1392.

Guivant, J., 2003. Pesticide use, risk perception and hybrid local knowledge: a case study from Southern Brazil. International Journal of Sociology of Agriculture and Food 11 (1), 41-51.

Hoffmann, J., Guardado, J., Keifer, M., Wesseling, C., 2006. Mortality among a cohort of banana plantation workers in Costa Rica. International Journal of Occupational and Environmental Health 12, 321-328.

IRET. 2010. Plaguicidas en Centro América. http://www.plaguicidasdecentroamer ica.info (accessed December 10, 2010.)

Jansen, K., 2000. Labour, livelihoods, and the quality of life in organic agriculture in Europe. Biological Agriculture and Horticulture 17 (3), 247-278.

Jansen, K., 2002. Plaguicidas y su regulación en Honduras. Ceiba 43 (2), 273-289.

Jansen, K., 2003. Crisis discourses and technology regulation in a weak state: responses to a pesticide disaster in Honduras. Development and Change 34 (1) 45-66.

Jansen, K., 2008. The unspeakable ban: the translation of global pesticide governance into Honduran National Regulation. World Development 36 (4), 575-589.

Kellehear, A., 1993. The Unobtrusive Researcher: A Guide to Methods. Allen \& Unwin.

Murillo-Sánchez, A., 1998. Incidencia de las políticas de importación de la Unión Europea (UE) sobre el desempeño económico y productivo de la actividad bananera de Costa Rica Centro Agronómico Tropical de Investigación y Enseñanza. Turrialba, Costa Rica.

Murray, D.L., 1994. Cultivating Crisis. The Human Cost of Pesticides in Latin America. University of Texas Press, Austin.

Murray, D.L., Taylor, P.L., 2000. Claim no easy victories: evaluating the pesticide industry's global safe use campaign. World Development 28 (10), 1735-1749.

Nygren, A., 1998. Struggle over meanings: reconstruction of indigenous mythology, cultural identity, and social representation. Ethnohistory 45 (1), 31-63.

Palis, F.G. Flor, R.J., Warburton, H., Hossain, M., 2006. Our farmers at risk: behaviour and belief system in pesticide safety. Journal of Public Health 28 (1), 43.

Penagos, H., 2002. Contact dermatitis caused by pesticides among banana workers in Panama. International Journal of Occupational and Environmental Health 8 $14-18$

PNUD-UCR, 2007. Atlas del desarrollo humano cantonal de Costa Rica, develando el desarrollo humano en Costa Rica. San José, Costa Rica.

Polidoro, Beth A., Dahlquist, Ruth M., Castillo, Luisa E., Morra, Matthew J., Somarriba, Eduardo, Bosque-Pérez, Nilsa, 2008. Pesticide application practices, pest knowledge, and cost-benefits of plantain production in the BribriCabécar Indigenous Territories, Costa Rica. Environmental Research 108 (1) 98-106.

Ramírez, F., Chaverri, F., de la Cruz, E., Wesseling, C., Castillo, L., Bravo, V., 2009. Importación de plaguicidas en Costa Rica: período 1977-2006. IRET_-Universidad Nacional, Heredia.

Rao, P., Quandt, S.A., Doran, A.M., Snively, B.M., Arcury, T.A., 2007. Pesticides in the homes of farmworkers: Latino mothers' perceptions of risk to their children's health. Health Education and Behavior 34 (2), 335.

República de Costa Rica, 2003. Reglamento para las actividades de la Aviación Agrícola. La Gaceta.

Rioux-Pelletier, M.E., 2009. Las dinámicas de la difusión de información sobre los plaguicidas y sus efectos sobre la salud en una comunidad de Costa Rica. M.Sc. Thesis in Communication. University of Quebec at Montreal, Canada.

Rodríguez, T., Younglove, L., Lu, C., Fúnez, A., Weppner, S., Barr, D., Fenske, R.A. 2006. Biological monitoring of pesticide exposures among applicators and their children in Nicaragua. International Journal of Occupational and Environmental Health 12 (4), 312-320.

Sherwood, S.G., 2009. Learning from Carchi. Agricultural modernisation and the production of decline. Ph.D. Dissertation, Wageningen University, Wageningen. 
Slutsky, M., Levin, J., Levy, B., 1999. Azoospermia and oligospermia among a large cohort of DBCP applicators in 12 countries. International Journal of Occupational and Environmental Health 5, 199-201.

Thrupp, L.A., 1988. Pesticides and policies: approaches to pest-control dilemmas in Nicaragua and Costa Rica. Latin American Perspectives 15 (4), 37-70.

Turner, B.S., 2001. Risks, rights and regulation: an overview. Health, Risk and Society 3 (1), 9-18.

van Wendel de Joode, B.N., De Graaf, I.A.M., Wesseling, C., Kromhout, H., 1996. Paraquat exposure of knapsack spray operators on banana plantations in Costa Rica. International Journal of Occupational and Environmental Health 2 (4), 294-304.

van Wendel de Joode, B., Wesseling, C., Kromhout, H., Monge, P., Garcia, M. Mergler, D., 2001. Chronic nervous-system effects of long-term occupational exposure to DDT. Lancet 357 (9261), 1014-1016.

Veal, A.J., 2006. Research Methods for Leisure and Tourism: A Practical Guide. Pearson Education.

Vellema, S.R., 2005. Regional cultures and global sourcing of fresh asparagus In: Fold, N., Pritchard, B. (Eds.), Cross-Continental Agro-Food Chains: Structures, Actors and Dynamics in the Global Food System. Routledge, London, pp. 124-136.

Vergara, A., Fuortes, L., 1998. Surveillance and epidemiology of occupational pesticide poisonings on banana plantations in Costa Rica. International Journal of Occupational and Environmental Health 4, 199-2001.
Wesseling, C., Ahlbom, A., Antich, D., Rodriguez, A.C., Castro, R., 1996. Cancer in banana plantation workers in Costa Rica. International Journal of Epidemiology 25 (6), 1125-1131.

Wesseling, C., Aragón, A., Rojas, M., Blanco, L., López, L., Soto, A., et al., 2006. Efectos del clorpirifos sobre la salud de trabajadores bananeros de La Lima, Honduras. Serie salud y trabajo 1.

Wesseling, C., Castillo, L., Elinder, C.G., 1993. Pesticide poisonings in Costa Rica. Scandinavian Journal of Work, Environment and Health 19 (4), 227-235.

Wesseling, C., Keifer, M., Ahlbom, A., McConnell, R., Moon, J.D., Rosenstock, L., et al., 2002. Long-term neurobehavioral effects of mild poisonings with organophosphate and n-methyl carbamate pesticides among banana workers. International Journal of Occupational and Environmental Health 8 (1), 27-34.

Wesseling, C., van Wendel de Joode, B., Monge, P., 2001. Pesticide-related illness and injuries among banana workers in Costa Rica: a comparison between 1993 and 1996. nternational Journal of Occupational and Environmental Health 7 (2), 90-97.

Wesseling, C., van Wendel de Joode, B., Keifer, M., London, L., Mergler, D., Stallones, L., 2010. Symptoms of psychological distress and suicidal ideation among banana workers with a history of poisoning by organophosphate or n-methyl carbamate pesticides. Occupational and Environmental Medicine.

World Health Organization, 2010. The WHO Recommended Classification of Pesticides by Hazard and Guidelines to Classification: 2009. World Health Organization, Geneva. 